\title{
MOITA LOPES, L. P. IDENTIDADES FRAGMENTADAS: A CONSTRUÇÃO DISCURSIVA DE RAÇA, GÊNERO E SEXUALIDADE EM SALA DE AULA. CAMPINAS, SP: MERCADO DE LETRAS, 2002, 232 PÁGS.
}

\author{
Resenhado por: Cibele Brandão
}

Com larga experiência em pesquisas ambientadas no contexto escolar, Moita Lopes elege, neste livro, a sala de aula como o contexto institucional adequado para análise da construção de identidades sociais, pois é a escola um dos principais espaços onde se consolidam os discursos de identidade.

Fruto de pesquisa realizada em aulas de leitura em língua materna (Partes I e II), o objetivo do livro é desenvolver a consciência crítica acerca do conhecimento que é construído na escola sobre as identidades sociais de raça, gênero e sexualidade, mediadas nas práticas de letramento. Para tanto, o autor faz um relato de natureza etnográfica sobre como aprendemos a ser o que somos na escola.

Apoiado em teorias socioconstrucionistas do discurso e das identidades sociais, Moita Lopes se opõe a uma visão essencialista ou fixa das identidades sociais. Ao contrário, enfatiza reiteradamente ao longo da obra a concepção da identidade como algo que se constrói nas práticas sociais, ou seja, o autor defende que a identidade não existe aprioristicamente, independentemente das ações dos sujeitos, mas, como representações, elas se constituem nas práticas discursivas com os outros, por meio das ações repetidas dos atores sociais.

Assim, o caráter mutante das identidades sociais possibilita, a qualquer momento da interação, reposicionamentos, questionamentos, negociações e, inclusive, a construção de novas identidades.

A preocupação com o que somos e como aprendemos a nos reconhecer como tal está no centro das discussões acadêmicas. Vivemos em um mundo conturbado, marcado por grandes transformações sociais e, por isso mesmo, constantemente expostos a múltiplos discursos e a várias atividades, o que nos leva a assumir identidades muitas vezes contraditó- 
rias e fragmentadas. Daí a justificativa para o título do livro, uma vez que a proposta do autor é investigar a constituição de identidades várias, com as quis as pessoas têm de conviver simultaneamente.

A obra é dividida em três partes interdependentes. A primeira enfoca a construção da diferença e da identidade de raça. A segunda trata da construção da sexualidade e do gênero e a terceira focaliza a desconstrução de identidades sociais em sala de aula.

O tema escolhido pelo autor, conforme já referido, é investigado no contexto de sala de aula e em situações de letramento. Desse modo, Moita Lopes procura desvendar como os seres sociais aprendem, nas práticas escolares, a se enquadrar em diferentes grupos identitários que (re)constituem as desigualdades e as contradições sociais da contemporaneidade.

$\mathrm{Na}$ primeira parte do livro, o autor demonstra que em uma sociedade multirracial, como é a brasileira, deve-se ir além do simples convívio com as diferenças. Extrapolar os limites da tolerância pressupõe o entendimento da origem das diferenças. A saída, então, é desvendar como se constroem as representações identitárias. Por meio da análise de dados interacionais, Moita Lopes estuda o processo de construção de identidade em uma sala de aula de leitura em que o texto base versa sobre o "Respeito às diferenças”. Aqui o autor denuncia a naturalização das diferenças nas práticas escolares, pelo fato de elas serem tratadas como inerentes às pessoas, e não como fruto de um processo de construção sociodiscursiva.

A segunda parte apresenta um questionamento sobre a exclusão da identidade homoerótica nas práticas discursivas escolares que versam sobre sexualidade. Como conseqüência desta prática discriminatória, o autor questiona também a omissão da escola quanto à função que esta deveria ter na construção de discursos emancipatórios.

Num momento em que conflitos entre raças, gêneros e, também, de sexualidade ameaçam a paz mundial, seria útil se pudéssemos refletir sobre nossas práticas, parando de promover ou incentivar a discriminação de grupos sociais desfavorecidos. Uma boa saída é adotar práticas que favoreçam os oprimidos. É o que sugere Moita Lopes no último capítulo, quando propõe a reconstrução das identidades de gênero e de sexualidade no discurso de sala de aula de línguas. A análise revela a possibilidade 
de transformação das identidades sociais por meio das práticas discursivas em que as pessoas atuam, sendo esta a discussão central do livro.

Em todo o conjunto da obra, as análises levam em conta, sobretudo, o agir humano e suas contingências e, em razão disto, a ética é privilegiada neste livro. Não obstante seus leitores naturais se encontrarem no circuito fechado da academia, onde o livro pode circular, já que os professores de $1^{\circ}$ e $2^{\circ}$ graus dificilmente teriam acesso a este volume, seja por desconhecimento de sua existência, seja por restrições financeiras, principalmente no caso dos professores da rede pública. Assim, é remota a possibilidade de o livro vir a servir para transformação das práticas escolares tradicionais e discriminatórias, como deseja o autor.

Contudo, não seria mal se os professores conseguissem interpretar a ideologia veiculada nas aulas de leitura e nas práticas escolares tradicionais. Isso permitiria que enxergassem o que realmente acontece. Mas só a rejeição a práticas discriminatórias não é o suficiente. É preciso que os professores propiciem práticas alternativas, com o objetivo de reduzir as injustiças sociais motivadas por questões de sexualidade, raça, gênero e, quem sabe, por mais algumas de outra ordem. 